3. Centers for Disease Control. Update: acquired immunodeficiency syndrome and human immunodeficiency virus infection among health-care workers. MMWR 1988;37:229-233,239.

4. Centers for Disease Control. Update: human immunodeficiency virus infections in health-care workers exposed to blood of infected patients. MMWR 1987;36:285-289.

5. Gioannini P, Sinicco A, Cariti G, Lucchini A, Paggi G, Giachino 0 . HIV infection acquired by a nurse. EurJ Epidemiol 1988;4:119120.

6. Muller 0, Moser R. HIV-1 disease in a Kampala hospital, 198589. Lancet 1990;335:236-237.

7. Hoofnagle JH, Seeff LB, Bales ZB, et al. Passive-active immunity from hepatitis B immune globulin. Ann Intern Med 1979;91:813818.

8. Centers for Disease Control. Update: universal precautions for prevention of transmission of human immunodeficiency virus, hepatitis B virus, and other bloodborne pathogens in health-care settings. MMWR 1988;37:377-382,387-388.

9. McGeer A, Simor AE, Low DE. Epidemiology of needlestick injuries in house officers. JInfect Dis 1990;162:961-964.

10. Mann JM, Francis H, Quinn TC, et al. HIV seroprevalence among hospital workers in Kinshasa, Zaire. Lack of association with occupational exposure. JAMA 1986;256:3099-3102.

11. Albertoni F, Ippolito G, Petrosillo N, et al. Needlestick injury in hospital personnel: a multicenter survey from central Italy. Infect Control Hosp Epidemiol 1992;13:540-544.

12. Mangione CM, Gerberding JL, Cummings SR. Occupational exposure to HIV: frequency and rates of underreporting of percutaneous and mucocutaneous exposures by medical housestaff. Am J Med 1991;90:85-90.
13. Heald AE, Ransohoff DE Needlestick injuries among resident physicians.] Gen Intern Med 1990:5:389-393.

14. Olaleye OD, Bernstein L, Ekweozor CC, et al. Prevalence of human immunodeficiency virus types 1 and 2 infections in Nigeria.J Infect Dis 1993;167:710-714.

15. Amazigo UO, Chime AB. Hepatitis-B virus infection in rural and urban populations of eastern Nigeria: prevalence of serological markers. East Afr Med J 1990;67:539-544.

16. English JFB. Reported hospital needlestick injuries in relation to knowledge/skill, design, and management problems. Infect Control Hosp Epidemiol 1992;13:259-264.

17. Whitby M, Stead P, Najman JM. Needlestick injury: impact of a recapping device and an associated education program. Infect Control Hosp Epidemiol 1991;12:220-225.

18. Haiduven DJ, DeMaio TM, Stevens DA. A five-year study of needlestick injuries: significant reduction associated with communication, education, and convenient placement of sharps containers. Infect Control Hosp Epidemiol 1992;13:265-271.

19. Ribner BS, Landty MN, Gholson GL, Linden LA. Impact of a rigid, puncture-resistant container system upon needlestick injuries. Infect Control 1987;8:63-66.

20. Gerberding JL, Littell C, Tarkington A, Brown A, Schecter WI? Risk of exposure of surgical personnel to patients' blood during surgery at San Francisco General Hospital. N Engl J Med 1990;322:1788-1793.

21. Sellick JA Jr, Hazamy PA, Mylotte JM. Influence of an educational program and mechanical opening needle disposal boxes on occupational needlestick injuries. Infect Control Hosp Epidemiol 1991:12:725-731.

\title{
TB Transmitted to Healthcare Worker from Intubated Neonate
}

\section{by Gina Pugliese, RN, MS Medical News Editor}

A healthcare worker is believed to have developed TB while caring for an intubated neonate with undiagnosed congenital TB. The 25-day-old infant was transferred to a university medical center (MC1) from another medical center (MC2) with a 1-day history of respiratory distress, vomiting, and poor feeding. Within 24 hours after admission to MC1 the infant required mechanical ventilation. Tracheal and gastric aspirates demonstrated $3+$ AFB on direct smear and $M$ ycobacterium tuberculosis was subsequently isolated. Precautions consisting of a private room and respiratory protection were instituted.
Eighty-six employees had direct exposure to the child at both medical centers. There were no tuberculin skin test (TST) converters among the 53 employees at MC2 who were TST negative at baseline. At MC1, the 33 employees with direct exposure to the child while intubated had a twostep TST baseline and a follow-up TST at 12 weeks using Tubersol R (5TU). All of these contacts were negative at baseline and one contact had a positive TST $(18.22 \mathrm{~mm}$ induration) at 12 weeks. She had assisted with suctioning the intubated infant three times prior to institution of isolation precautions. Her chest radiograph revealed no active disease, and she denied any exposures outside the hospital and had used AFB precautions in car- ing for other patients suspected of having TB. All of these suspect patients were smear and culture negative to date.

These data suggest that TB may be transmissible from intubated neonates and future recommendations for pediatric TB isolation guidelines should consider this.

FROM: Costello A, Galsby C, Cantwell M, Shehab Z. Contact follow-up after exosure involving a newborn with congenital $\mathrm{TB}$ at two medical centers. 33rd Interscience Conference on Antimicrobial Agents and Chemotherapy; New Orleans, LA; October 17-20, 1993. Abstract 1355. 